DOI: 10.20472/IAC.2017.034.032

\title{
JAROSLAV MEČKOVSKI
}

Vilnius University, Lithuania

TEODORAS MEDAISKIS

Vilnius University, Lithuania

TADAS GUDAITIS

Vilnius University, Lithuania

\section{SECOND PENSION PILLAR PARTICIPANTS' BEHAVIOR OVER LIFE CYCLE: LITHUANIAN CASE}

\begin{abstract}
:
Defined contribution pension pillars often requires participants to take an active role in selecting pension fund during the whole accumulation period. It is expected that pension fund participant will select appropriate investment strategy and investment risk during different stages of the accumulation phase and years left till the retirement. In this paper, we have analyzed the behavior of second pillar pension funds' participants in Lithuania from the beginning of second pension pillar establishment (2004) till the 2016 Q3. The aim of the study is to evaluate how rational second pension pillar participants in decisions on selecting accumulation rate, appropriate pension fund (investment strategy and investment risk) and changing the pension fund over accumulation period and during different stages of development (peaks and bottoms) in the financial markets. The results show, that second pension pillar participants are rational on selecting participation rates. However, it also highlighted problems in second pension pillar. Majority of pension funds participants have selected inappropriate pension fund (investment strategy and investment risk) evaluating the accumulation period, which have left till the retirement. Participants are passive and tend not to change pension fund during accumulation period. Pension fund participants, which have changed pension fund, made irrational decisions and have chosen inappropriate pension fund (investment strategy and investment risk): in case of peak period in stock markets, majority of second pension pillar participant have changed pension funds, by switching from the fund which have lower proportion of equities to the fund which has higher proportion of equities or have change pension fund to the fund in the same investment risk category. Moreover, in case of bottom period in stock markets the majority of participants did vice versus - switched from funds with higher proportion of equities to pension fund with lower proportion of equities.
\end{abstract}

\section{Keywords:}

Pension funds, Behavior finance, Life cycle investments.

JEL Classification: J32, D14, D91 